\title{
Liberalisme dan Rasionalitas sebagai Basis Rule of Law: Perspektif Gerald Turkel
}

\author{
Aditya Yuli Sulistyawan \\ Fakultas Hukum Universitas Diponegoro \\ adityayulisulistyawa@lecturer.undip.ac.id
}

\begin{abstract}
This paper is intended to discuss Gerald Turkel's thoughts on liberal society, rationality, and rule of law, as well as the author's analysis of the paradigms that underlie these thoughts. This article focuses on the scope of social change by analyzing how rule of law has made the change from classical liberalism and competitive capitalism to corporate liberalism and corporate capitalism in the United States. Through the study of literature, the author can conclude that there is a common thread between the relationship between classical liberalism, competitive capitalism and the rule of law ideology, in this case the rule of law is explained based on the typology of legal decision making put forward by Max Weber and his views on rationality and social action. Next, a philosophical study by the author paradigmatically against the thought of Turkel concluded that Turkel's writings were still in the understanding of the positivism paradigm. However, this paradigmatic study is not the only one because through this writing, the reader is invited to slowly (but surely) enter the "world" paradigm of critical theory et. al. Therefore, among the paradigmatic ranges, Turkel actually rests on the post-positivism paradigm.
\end{abstract}

Keywords: liberal society; rationality; the rule of law; paradigm. 


\begin{abstract}
Abstrak
Artikel ini membahas pemikiran Gerald Turkel mengenai masyarakat liberal, rasionalitas, dan rule of law, serta paradigma yang memayungi pemikiran tersebut. Artikel ini difokuskan pada lingkup perubahan sosial dengan menganalisis bagaimana rule of law telah membuat perubahan dari liberalisme klasik dan kapitalisme kompetitif menuju liberalisme korporasi dan kapitalisme korporasi di Amerika Serikat. Melalui studi literatur, artikel ini menyimpulkan bahwa terdapat benang merah hubungan antara liberalisme klasik, kapitalisme kompetitif dan ideologi rule of law, dalam hal ini rule of law yang dijelaskan berdasarkan tipologi pengambilan keputusan hukum yang dikemukakan oleh Max Weber dan pandangannya tentang rasionalitas dan tindakan sosial. Telaah filsafati yang dilakukan secara paradigmatik terhadap pemikiran Turkel menyimpulkan bahwa tulisan Turkel masih berada dalam pemahaman paradigma positivisme. Namun demikian, telaah paradigmatik ini bukanlah satu-satunya, karena melalui tulisan tersebut pembaca diajak untuk secara perlahan-lahan (namun pasti) memasuki "dunia” paradigma critical theory. Oleh karena di antara rentang paradigmatik itu, Turkel sejatinya berpijak pada paradigma postpositivisme.
\end{abstract}

Kata kunci: masyarakat liberal; rasionalitas; the rule of law; paradigma.

\title{
A. Pendahuluan
}

Artikel ini membahas pemikiran Gerald Turkel mengenai masyarakat liberal dan rasionalitas sebagai basis dari rule of law, serta menganalisis paradigma yang memayungi pemikiran tersebut. Artikel ini tidak bermaksud membahas pemikiran Turkel secara keseluruhan, melainkan pada apa yang ditulisnya dalam buku Law and Society: Critical Approaches, khususnya bab ketiga, "Liberal Society, Rationality, and the Rule of Law". Pembahasan terhadap tulisan Turkel ini dianggap penting karena tiga hal. Pertama, buku ini mampu menampilkan hubungan antara liberalisme, rasionalitas, dan rule of law dengan baik. Sebagai eksponen aliran hukum dan masyarakat (law and society) dari Delaware University, Amerika Serikat, Turkel berhasil menyampaikan pemikirannya dalam ontologi realisme kritis terhadap hukum. Dalam buku tersebut, telaahnya yang populer di 
antaranya adalah upayanya dalam membahas tipologi Max Weber tentang studi hukum dengan sangat terperinci. Menurutnya, ada tiga macam pendekatan yang dapat digunakan dalam telaah hukum dan masyarakat, yaitu pendekatan moral, pendekatan ilmu hukum, dan pendekatan sosiologis. ${ }^{1}$ Kontribusi keilmuan inilah yang menjadikan pemikiran Turkel senantiasa relevan untuk menjelaskan hukum dalam konteks masyarakat, termasuk dalam memahamkan konsep the rule of law dalam kenyataan sosial yang ada.

Kedua, dalam konteks kehidupan modern, atau dalam kaitannya dengan hukum berarti hukum modern, konsep the rule of law dianggap sebagai yang paling ideal untuk mewujudkan supremasi hukum. Rule of law sendiri merupakan konsep yang berkaitan dengan hubungan dan tindakan atau perbuatan manusia yang diatur oleh sesuatu yang terkodifikasi, impersonal, dan prosedur yang tidak memihak, dan peraturan-peraturan yang diterapkan secara sama (equal) dan adil (fair) untuk semua orang. ${ }^{2}$ Pemahaman ini sejalan dengan rule of law dalam pendekatan formal yang dimaknakan bahwa hukum sebagai instrumen tindakan pemerintah. ${ }^{3}$ Dalam rule of law, orang-orang berbagi keyakinan bahwa hubungan dan tindakan mereka "dipaksa" oleh peraturan dan institusi hukum, dan lembaga-lembaga yang dibentuk dengan ekspektasi yang serupa. Dalam hal ini, hukum merupakan sumber terakhir dari kontrol sosial. Sebagaimana dikatakan Steven Vago, hukum pada dasarnya memiliki tiga fungsi, yaitu sebagai kontrol sosial (social control), penyelesaian

1 Gerald Turkel, Law and Society: Critical Approaches (Toronto: A. Simon \& Schuster Company Needham Heights, MA., 1996.), hlm. 10.

2 Menurut Unger, dalam pengertian yang paling luas, rule of law didefinisikan lewat gagasan tentang sifat netral (neutrality), seragam (uniformity), dan dapat diprediksikan (predictability). Penggunaan kekuasaan pemerintah harus berlangsung di dalam batasan-batasan peraturan yang berlaku bagi cukup banyak kategori orang dan tindakan. Segenap peraturan ini, apapun bentuknya, harus diberlakukan secara seragam. Roberto M. Unger, Teori Hukum Kritis: Posisi Hukum dalam Masyarakat Modern (Bandung: Penerbit Nusa Media, 2010), hlm. 234.

3 Achmad Irwan Hamzani, "Menggagas Indonesia sebagai Negara Hukum yang Membahagiakan Rakyatnya”, Yustisia Jurnal Hukum, 3, 3 (2014), hlm. 137. 
sengketa (dispute resolution), dan alat pengatur masyarakat (social engineering). ${ }^{4}$ Ini berarti, selain untuk menyelesaikan sengketa, hukum juga berfungsi untuk melakukan kontrol sosial dan mengatur masyarakat.

Karena itu, pengaturan hukum (regulasi) terjadi hampir dalam semua sektor kehidupan. Berbagai sektor kehidupan yang saling berhubungan, dipilah-pilah untuk kemudian direduksi menjadi sektor yang saling berhadapan sehingga dibutuhkan peraturan untuk mengatur atau menjaga kekompakannya. ${ }^{5}$ Padahal, apa yang menjadi tradisi modern ini sesungguhnya sulit ditemukan pada masyarakat tradisional. Rouland mengungkap bahwa hukum bukanlah suatu obyek dengan pembatasan yang tak berubah-ubah, melainkan lebih sebagai suatu cara dalam memahami hubungan-hubungan sosial. ${ }^{6}$

Ketiga, dalam kaitannya dengan rule of law, beberapa sumber atau basis sosial yang melatarinya penting untuk diulas. Basis sosialnya itu dalam hal ini adalah liberalisme dan kapitalisme. Dalam perkembangannya, model liberalisme klasik (classical liberalism) dan kapitalisme kompetitif (competitive capitalism), yang sesungguhnya menjadi latar belakang rule of law, telah bergeser menuju liberalisme dan kapitalisme korporasi. Tulisan Turkel dalam buku tersebut mengungkap pengaruh liberalisme dan kapitalisme terhadap rule of law, dan karenanya menarik untuk didiskusikan lebih lanjut.

Dalam membahas liberalisme dan kapitalisme sebagai basis sosial rule of law menurut Turkel, artikel ini setelah bagian ini akan membahas hubungan antara liberalisme dan rule of law serta kapitalisme dan rule of law. Bagian berikutnya ingin menelaah secara paradigmatik ulasan Turkel tentang liberalisme dan kapitalisme dalam kaitannya dengan rule of law. Dalam telaah paradigmatik ini ingin ditunjukkan bahwa pemikiran Turkel sesungguhnya masih terbingkai dalam positivisme, lebih tepatnya adalah paradigma pos-

4 Steven Vago, Law and Society (New Jersey: Prentice Hall, edisi keempat, 1994), hlm. 13-15.

5 Bernard L. Tanya, Hukum dalam Ruang Sosial (Yogyakarta: Genta Publishing, 2011), hlm. 143.

6 Tanya, Hukum dalam Ruang Sosial, hlm. 143. 
positivisme.

\section{B. Liberalisme, Rasionalitas, dan Rule of Law}

\section{Pertalian Liberalisme dan Rule of Law}

Doktrin rule of law dianut oleh sistem anglo saxon yang digagas oleh Albert Venn Dicey menjelaskan dua hal terkait dengan rule of law, yaitu, pertama, embrionik rule of law adalah kemahakuasaan atau supremasi tak terbantahkan di seluruh negara bagian dan pemerintah pusat. Kedua, dariembrionik rule of law yang berhubungan erat dengan yang pertama, ialah peraturan atau supremasi hukum. ${ }^{7}$ Supremasi hukum dibutuhkan dalam rangka membangun stabilitas nasional untuk membangun negara demokrasi yang baik. Berdasarkan teori The New Way to Understand Why the Nation Rise and Fall karya Brumer disebutkan bahwa negara yang terbuka terhadap keterbukaan dan kebebasan justru dapat memiliki stabilitas yang mampu mengatasi guncangan internal tanpa harus khawatir negara itu akan jatuh. ${ }^{8}$

Rule of law menjadi lengkap ketika dikaitkan dengan gerakan sosial dan pola-pola kehidupan sosial yang menganggap kebebasan individu sebagai prinsip dasar dari organisasi sosial. Menurut ahli sejarah E.P. Thompson, rule of law muncul di Inggris sebagai hasil dari keinginan rakyat untuk memperoleh kebebasan dan kemerdekaan dari penindasan kerajaan (monarki), kekuasaan negara yang sewenang-wenang dan kelas sosial yang kuat. Pada intinya dari pengalaman Amerika, mulai dari perang kemerdekaan melawan Inggris sampai dengan ratifikasi Konstitusi Amerika Serikat 1789, perang sipil tahun 1860 dan New Deal 1930 dan seterusnya, merupakan upaya untuk mengamankan kebebasan dan kemerdekaan individual melalui hukum.

Prinsip-prinsip hukum, seperti Bill of Rights (sepuluh amandemen

7 Zahermann Armandz Muabezi, "Negara Berdasarkan Hukum (Rechtstaats) Bukan Kekuasaan (Machtstaat)", Jurnal Hukum dan Peradilan, 6, 3 (2017), hlm. 424.

8 Wicipto Setiadi, "Pembangunan Hukum dalam Rangka Peningkatan Supremasi Hukum”, Jurnal Rechtsvinding: Media Pembinaan Hukum Nasional, 1, 1 (2012), hlm. 5 . 
pertama dari konstitusi Amerika Serikat yang membatasi kekuasaan pemerintah), merupakan dasaruntuk menetapkankebebasan individu dan hak-hak hukum. Amandemen The Civil War dalam Konstitusi melarang adanya perbudakan, memberikan hak untuk memilih, dan memberikan perlindungan dari kekuasaan pemerintah. Legislasi New Deal seperti misalnya Undang-undang Keamanan Sosial (Social Security Act) berusaha untuk membuat kehidupan dan kebebasan individu lebih aman secara ekonomis dengan cara memberikan pensiun hari tua. Jadi, rule of law berakar dari pengakuan bahwa kebebasan dan keamanan individu dicapai melalui sebuah masyarakat yang diatur berdasarkan hukum yang membatasi kekuasaan negara, persamaan hukum dan hak-hak ekonomi.

Walaupun terdapat ikatan yang kuat antara rule of law dan keinginan untuk menetapkan kebebasan politik individu dan kebebasan individu untuk berkeyakinan dan beragama, berbagai pemikir telah mempertimbangkan hubungan antara kapitalisme kompetitif dan rule of law. Hasil survei Weber menunjukkan bahwa hanya hukum yang rasional dan modern, atau ketentuan yang formal rasional dan logis, yang mendorong perkembangan kapitalisme melalui penciptaan kondisi yang stabil dan dapat dikondisikan. ${ }^{9}$ Para pemikir ini sepakat bahwa suatu ekonomi pasar yang kompetitif merupakan syarat rule of law sekaligus sebagai bagian dari hasil dari rule of law. Menurut Gerald Turkel, sebuah ekonomi pasar yang kompetitif memiliki lima ciri utama:

1. Adanya kepemilikan yang luas terhadap properti, tanah dan asetaset bisnis;

2. Pasar diorganisir melalui interaksi dari kegiatan jual beli barang dan jasa usaha kecil satu sama lain. Kegagalan satu atau kelompok bisnis tersebut tidak memberikan pengaruh yang serius terhadap perekonomian negara;

3. Bisnis dijalankan langsung oleh pemiliknya, dan tidak dilakukan oleh manajer;

4. Pekerja bebas untuk berpindah-pindah pekerjaan;

9 Bruce R Scott, Capitalism, Its Origin and Evolution as a System of Governance (New York: Springer, 2011), hlm. 44. 
5. Ekonomi diatur sendiri melalui keputusan dan tindakan dari pemilik usaha, pekerja dan konsumen. Tingkat tinggi lapangan kerja dan pertumbuhan ekonomi akan dihasilkan dari relasi pasar dari masyarakat tanpa usaha pemerintah untuk mendorong lapangan kerja atau dukungan terhadap dunia usaha.

Para ahli mempertahankan bahwa kapitalisme kompetitif paling terlayani oleh sebuah tatanan hukum yang berbasis rule of law: hukum yang tidak memihak. Dalam rule of law, pertukaran di dalam pasar, perencanaan dan implementasi investasi untuk menghasilkan keuntungan pribadi, kepemilikan properti dan kewajiban kontraktual akan diberikan prediktabilitas dan keamanan. Oleh karena kekuatan ekonomi dan pengambilan keputusan tersebar di seluruh masyarakat, maka peraturan hukum yang stabil yang secara merata diterapkan kepada setiap orang akan membuat kehidupan menjadi jelas dan dapat diprediksikan.

Selain itu, rule of law tidak berorientasi untuk mengarah pada tujuan sosial atau penyelesaian problem-problem sosial melalui pembuatan dan implementasi kebijakan. Hukum bukan sebuah arena untuk penyelesaian permasalahan kemiskinan, pengangguran, atau ketiadaan asuransi kesehatan. Sebaliknya, rule of law menjaga stabilitas tatanan individu dan bisnis untuk mengejar keuntungan ekonomi mereka. Jadi ini merupakan kerangka untuk menjalankan aktivitas sosial dan ekonomi. Rule of law memperlakukan sama dan tidak memihak terhadap setiap orang.

Di luar kaitan antara kapitalisme kompetitif dan rule of law, liberalisme klasik merupakan salah satu jenis budaya yang menetapkan dan memberikan nilai terhadap sebuah tipe individu dan cara pendekatan tentang dunia. Dalam hal ini terdapat percampuran yang sangat mendalam antara hukum, kebebasan individu, pribadi dan masyarakat. Tentu yang mendasari liberalisme klasik adalah pemahaman yang sangat individual dan legalistik tentang pribadi dan masyarakat. Liberalisme klasik memahami masyarakat sebagai hubungan antara orang yang berinteraksi dengan berbasis pada kekuatan harta kekayaannya untuk memperoleh keuntungan individu. Dalam konteks ini, Andrew Altman menulis: "There can be 
no doubt that a vital element of liberal legal philosophy is the principle that a society ought to operate under the rule of law". Dengan demikian elemen paling penting dari liberal legal philosophy adalah prinsip rule of law. ${ }^{10}$

Ketika diskusi dengan pendekatan positivistis terhadap hukum dan masyarakat telah ditunjukkan, hukum menjadi lebih berkembang dan dominan ketika masyarakat menjadi lebih kompleks. Masyarakat menjadi lebih condong kepada rule of law ketika organisasi sosial menjadi lebih kompleks, aktivitas ekonomi diatur melalui kompetisi dan pasar, harta kekayaan dimiliki secara privat, identitas individu menjadi lebih penting daripada identitas kolektif dan masyarakat menjadi lebih beragam secara etnis maupun agama. Dalam kondisi seperti ini, hukum menjadi cara yang semakin dominan untuk menyelesaikan sengketa dan mengendalikan tindakan-tindakan individu.

Pola kehidupan sosial ini memperkuat kecenderungan ke arah melemahnya hubungan kedekatan dan kemasyarakatan. Hal ini mendukung adanya pemisahan antara dunia hukum publik dan politik dengan bidang yang lebih pribadi mengenai relasi-relasi pasar, kehidupan keluarga dan pola-pola yang terkait (agama, politik dan intelektual) yang berbasis pada kebebasan individu sebagai aktor utama dalam masyarakat. Ketika nilai-nilai agama, moralitas dan politik menjadi ciri kehidupan pribadi dan kebebasan individu, hukum hadir menjadi lebih independen dan menjadi sumber yang meresap dari peraturan sosial.

Ketika rule of law berakar pada prinsip-prinsip kebebasan dan politik individu dan persamaan moral seluruh individu, hal ini juga merupakan kekayaan budaya yang mendukung tatanan hukum. Dalam berbagai arena internasional, rule of law juga digunakan sebagai cara untuk melegitimasi suatu tindakan.

Membaca uraian Gerald Turkel di atas mengenai rule of law, konsep hukum tersebut merupakan konsep utama yang menunjukkan pemahaman hukum dalam bingkai worldview legal positivism. Aliran ini memaknai hukum sebagai law as what it is written in the books,

10 FX. Adji Samekto, Justice Not for All (Yogyakarta: Genta Press, 2008), hlm. 53. 
yakni kaidah-kaidah hukum positif yang berlaku umum in abstracto di suatu waktu/tempat tertentu. Bisa dikatakan bahwa aliran ini memahami hukum sebagai ius constitutum, yaitu "hukum yang ada dan berlaku”. Bagi aliran ini, hukum terbit sebagai produk eksplisit suatu sumber kekuasaan politik tertentu yang berlegitimasi. Dalam hal ini, hukum utamanya terwujud sebagai perintah-perintah eksplisit yang secara positif telah terumus jelas guna menjamin kepastiannya, seperti misalnya peraturan perundang-undangan yang berlaku secara nasional di suatu negara. Untuk itu, dapat dikatakan bahwa operasi aliran-aliran tersebut didasarkan utamanya pada norma positif legislatif dari ranah normatif positif. ${ }^{11}$ Demikianlah dapat dimengerti bahwa prinsip rule of law merupakan prinsip utama yang menuntun pemahaman legal positivism.

\section{Rasionalitas dan Rule of Law}

Tipe ideal hukum dan masyarakat yang digagas Max Weber membantu untuk mengapresiasi peran hukum sebagai fitur penting dalam perkembangan sosial dan budaya yang membentuk aksi-aksi dan institusi-institusi sosial. Keyakinan dan pemahaman yang dimiliki bersama yang diberikan melalui hukum membuat masyarakat mengkoordinasikan aktivitasnya secara lebih baik dan berguna dalam merencanakan proyek-proyek. Hukum menyediakan seperangkat makna mengenai hal-hal seperti properti/kepemilikan, tanggung jawab, kewajiban, dan aturan untuk interaksi yang menjadi latar belakang bagi manusia dalam membuat komitmen kepada orang lain dan merencanakan aktivitasnya secara bersama. Pendekatan Weber pada hukum dan masyarakat memberikan pemahaman yang lebih baik mengenai peran hukum sebagai ciri penting dalam perkembangan sosial dan budaya. Hukum modern berkembang sebagai bagian dari masyarakat sosial yang semakin hari semakin didasarkan pada hubungan sosial impersonal, rasional, dan dapat diperhitungkan.

11 Erlyn Indarti, "Diskresi dan Paradigma: Sebuah Telaah Filsafat Hukum”, Pidato Pengukuhan Guru Besar Filsafat Hukum pada Fakultas Hukum Universitas Diponegoro (Semarang: Badan Penerbit Undip, 2010), hlm. 21. 
Ciri dalam rasionalitas modern memiliki dua dimensi yang paling penting untuk suatu aksi sosial. Di satu sisi, rasionalitas adalah suatu cara di mana orang memahami aksi mereka. Di sisi lain, rasionalitas adalah ciri atau corak dari keteraturan sosial. Sebagai contoh, kapitalisme adalah suatu bentuk aksi ekonomi rasional individu dalam memahami dan mengkoordinasikan aktivitas ekonomi seharihari mereka dengan mengalkulasikan investasi, keuntungan, dan pendapatan. Di waktu yang sama, kapitalisme adalah keteraturan sosial yang didasarkan pada, di atas hallain, pengekspresian nilai dalam hal uang dan praktik akuntansi modern. Lebih lanjut, baik rasionalitas individu sehari-hari dan praktik akuntansi pada perusahaan bisnis cenderung saling melengkapi dan saling menguatkan satu sama lain. Rasionalitas individual sehari-hari ini sangat mungkin akibat dari institusi yang dilandaskan pada makna rasional.

Dalam masyarakat modern, lika-liku kehidupan menjadi terasionalisasi karena semakin dilandaskan pada aturan, kalkulasi, dan prediksi keluaran/hasil yang impersonal. Aktivitas sehari-hari yang dilakukan orang-orang pada ekspektasi masa depan mereka (pergi ke sekolah, bersiap meniti karir, belanja untuk makan malam, merencanakan liburan, pergi ke dokter) dilandaskan pada keyakinan mengenai masyarakat sebagai pola hubungan yang stabil, teratur yang dapat dipertanggungjawabkan secara rasional. Rasionalitas aktivitas sehari-hari tersebut dapat terjadi, sebagian, karena bagian besar dari kehidupan (ekonomi, organisasi sosial, pemerintahan, dan hukum) dibentuk oleh cara-cara yang rasional.

Rasionalitas dalam aktivitas ekonomi didasarkan pada perhitungan biaya, benefit dan keuntungan lainnya. Sebagai aktor ekonomi, individu terarah pada kerja dan konsumsi melalui penggunaan uang, yang membuat mereka mengalkulasikan pendapatan, pengeluran, dan kemakmuran mereka. Akuntansi dan budgeting modal adalah dasar untuk pengorganisasian produksi, marketing, dan distribusi. Efisiensi ekonomi, yakni, alokasi berbagai sumber daya untuk mencapai target individu dan kelompok, menjadi cara yang paling penting dalam menginterpretasikan organisasi ekonomi, produksi, dan konsumsi. 
Sedangkan dalam birokrasi, bentuk modern dari organisasi sosial, juga didasarkan pada rasionalitas. Birokrasi pada dasarnya adalah cara mengorganisasikan pengetahuan teknis dan ilmiah khusus untuk menyelesaikan tujuan yang ditentukan secara teknis. Di dalam birokrasi terdapat berbagai macam ahli yang menjadi suatu susunan organisasi yang diatur oleh sebuah peraturan administratif yang disusun oleh sebuah otoritas.

Seperti juga organisasi sosial dan ekonomi yang menjadi lebih rasional, demikian juga negara modern. Rasionalitas dalam negara modern meningkat dalam aksi politik, meningkatkan kekuatan pemerintah, dan konsentrasi melawan berbagai kekerasan. Negara modern berkonsentrasi pada kekuatan, khususnya pada instrumen kekuatan dan kekerasan, ke dalam susunan organisasi yang diatur secara birokratif. Partai politik berjuang untuk memenangkan kekuasaan dalam rangka menggunakan kekuatan untuk memenuhi keinginan dan nilai-nilai pendukungnya, dan paling penting, untuk mengisi posisi-posisi (jabatan) dalam negara.

Dalam berbagai arena tersebut terdapat perbedaan prinsip rasionalitas. Institusi serta pola aksi ekonomi, birokrasi, dan politis didasarkan pada berbagai prinsip rasionalitas yang berbeda. Rasionalitas ekonomi berpusat pada efisiensi ekonomi dan alokasi sumber daya yang didasarkan pada kebutuhan akan rasionalitas dalam distribusi sumber daya yang terbatas. Rasionalitas birokrasi berfokus pada mengorganisir pengetahuan dan menentukan serta merealisasikan target. Negara berfokus pada mengakumulasikan dan mengkonsentrasikan kekuatan dalam rangka mengamankan wilayah dan kehidupan sosial.

Pola rasionalitas tersebut, walau berbeda, umumnya cenderung mendukung satu sama lain. Namun, terdapat tekanan dan konflik di antara mereka. Maka, efisiensi ekonomi memerlukan beberapa langkah organisasi birokratik untuk mengkoordinasikan bentuk pengetahuan dan aktivitas teknis. Pada saat yang sama, birokrasi tak memilikiprinsipefisiensiekonomiuntukmembatasipertumbuhannya, walaupun pertumbuhannya harus ditahan oleh keterbatasan finansial dan sumber daya material. Pada saat yang sama, susunan sosial 
yang berjalan bersama rasionalitas ekonomi memerlukan beberapa langkah yang menunjukkan kekuatan negara.

Dalam konteks ini, hukum mengatur segala tarik ulur dan konflik pada seluruh arena masyarakat sosial modern ini. Oleh karena perbedaan rasionalitas yang membentuk kehidupan sosial modern yang berakibat pada berbagai masalah dan hubungan yang kompleks, hukum menjadi semakin penting untuk memastikan dan mengatur hubungan serta aksi yang terjadi. Aspek inti dari aktivitas ekonomi yang rasional rasional, mulai dari suplai uang hingga kontrak properti, secara legal ditentukan dan diatur. Kekuatan negara, yang dihadirkan untuk menyelesaikan konflik ekonomi pada properti dan kontrak serta untuk mempertahankan keteraturan sosial, penting untuk aktivitas-aktivitas ekonomi yangrasional, keduanya diatur dan ditentukan oleh hukum. Organisasi birokrasi didasarkan pada aturan dan definisi legal yang dikodifikasi oleh otoritas. Maka, hukum ini lebih dari pola norma dan institusi rasional yang dibentuk dalam kehidupan sosial modern. Hukum memainkan peran besar dalam mengatur kehidupan sosial.

Tipologi hukum yang dibuat Weber berfokus pada cara-cara aturan hukum yang digunakan untuk memutuskan kasus-kasus tertentu. Tipologi ini terutama berkaitan dengan pola-pola spesifik mengenai makna, prosedur, dan lembaga yang terlibat dalam pembuatan keputusan hukum. Konsisten dengan banyak diskusi tentang pendekatan ilmu hukum, tipologi ini berfokus pada hakim dan keputusan mereka sebagai inti dari hukum. Sementara Weber menganggap bahwa hukum dalam kaitannya dengan berbagai struktur sosial, lembaga-lembaga dan makna, sangat prihatin dengan pendekatan ilmu hukum (jurisprudence): hukum pada dasarnya adalah tentang hakim yang membuat keputusan hukum pada kasus-kasus tertentu.

Dalam menganalisis hukum dengan cara ini, Weber berusaha untuk menafsirkan pola yang berbeda dari penilaian dalam hal hukum yang rasional. Sebagai hukum yang rasional, berarti sejauh mana prinsip-prinsip hukum umum dan aturan secara konsisten dan jelas diterapkan untuk kasus-kasus tertentu. Dalam bentuk yang paling 
rasional, hukum adalah peraturan yang secara internal konsisten, dengan bentuk yang secara logis koheren. Hakim akan memutuskan peristiwa-peristiwa hukum tertentu dengan berdasarkan hukum serta prinsip-prinsip hukum yang terkait peristiwa tersebut.

Menggunakan dua dimensi dasar dari hukum yang rasional, pembuatan keputusan hukum dapat diklasifikasikan mulai dari yang kurang rasional sampai pada yang paling rasional. ${ }^{12}$ Kedua dimensi ini disebut formalitas dan rasionalitas. Formalitas adalah menyangkut independensi lembaga-lembaga dan prosedur-prosedur hukum dari semua lembaga sosial dan prosedur, termasuk keluarga, politik, ekonomi, dan agama. Rasionalitas adalah ketergantungan pada prinsip-prinsip hukum dan aturan khusus untuk membuat keputusan yang logis dapat diterapkan pada kasus-kasus tertentu. Ketika formalitas dan rasionalitas digabungkan, maka dapat dikonstruksikan empat tipe ideal hukum. Ke empat tipe hukum ini dapat digunakan untuk menganalisis bagaimana kombinasi yang berbeda dalam memandang hukum yang rasional.

Tabel 1. Tipe Hukum dalam Derajat Rasionalitas

\begin{tabular}{lcc}
\hline \multicolumn{1}{c}{ Tipe Hukum } & $\begin{array}{c}\text { Formalitas (Kemerdekaan } \\
\text { Institusional dan Prosedural) }\end{array}$ & Rasionalitas \\
\hline Irasional Substantif & - & - \\
Irasional Formal & + & - \\
Rasional Substantif & - & + \\
Rasional Formal & + & + \\
\hline
\end{tabular}

Pengambilan keputusan hukum yang disebut irasional substantif adalah yang tingkat rasionalitasnya rendah karena tidak

12 Weber meminimalkan konsekuensi logis dari kenyataan dengan mengemukakan Werturteilsfreiheit, bebas dari pertimbangan nilai. Berdasarkan konsep ini, perspektif yang murni bersandar pada nilai, tidak akan bisa diberi landasan rasional. Bahkan irasionalitas seperti ini berada di luar wilayah yang ilmiah. Ketika sudut pandang subyektif diterima, analisis sosial bisa dan harus dibebaskan dari pertimbangan nilai. Dengan jalan ini, analisa sosial akan memperoleh hasil obyektif, yaitu hasil yang secara intersubjektif berlaku bagi semua peneliti yang berkompeten. Baca Thomas McCarthy, Teori Kritis Jurgen Habermas, terj. Nurhadi (Yogyakarta: Kreasi Wacana, 2006), hlm. 187. 
memiliki lembaga, prosedur, atau pengetahuan yang independen. Hukum tidak dibedakan dari lembaga dan pola pengetahuan lainnya. Hukuman dibuat berdasarkan kasus per kasus oleh orang yang tidak tidak secara khusus terlatih dalam prosedur hukum, tidak secara khusus menempati peran hukum, dan yang tidak membuat penilaian dengan memberikan alasan keputusan mereka. Keputusan didasarkan pada wawasan dan kebijaksanaan dari pembuat hukum yang mencerminkan kemampuan unik pribadi pembuat hukum untuk membuat keadilan.

Tipe irasionalitas formal memiliki prosedur spesifik yang digunakan untuk membuat keputusan hukum, memiliki tingkat integritas prosedural yang lebih tinggi dibandingkan tipe irasional substantif. Prosedur irasional formal tidak berusaha untuk menganalisis kejadian dan tidak dibatasi dengan alasan, tetapi mengikuti aturan prosedural yang sangat ketat. Dengan kata lain, pengambilan keputusan irasional formal tidak mencoba untuk menggambarkan kasus dalam hal motif dan keadaan hukum yang relevan untuk membuat keputusan tentang legalitas atau ilegalitas pelaku dan tindakannya. Sebaliknya, menentukan bersalah atau tidak dicapai dengan menerapkan prosedur.

Rasionalitas substantif mengombinasikan antara ketiadaan lembaga dan prosedur dengan alasan pembuatan keputusan. Alasan yang tersedia bukan secara khusus merupakan alasan hukum, melainkan norma, prinsip, aturan atau fakta yang non hukum. sedangkan rasionalitas formal adalah tipe ideal dari hukum rasional. Tipe ini memiliki prosedur dan lembaga hukum independen tingkat tertinggi yang dikombinasikan dengan pola pengambilan keputusan yang ada di dalam batas-batas intelektual hukum. Keputusan didasarkan pada pengetahuan hukum yang meliputi prinsip-prinsip umum hukum, preseden, dan aturan-aturan yang menentukan relevansi dan fakta laporan hukum.

Tipologi pembuatan putusan hukum sendiri sesungguhnya bervariasi, mulai dari yang tingkat rasionalitasnya rendah sampai yang sangat rasional. Dalam dunia nyata, hal ini dapat dianalisa dari berbagai putusan hukum yang menunjukkan tingkat perbedaan 
rasionalitasnya. Ini merupakan elemen dan substansi irasionalitas dari hukum modern.

Berakar dari beberapa pendekatan sociological interpretive, ${ }^{13}$ Douglas Maynard menganalisa struktur percakapan dan pengungkapan cerita di pengadilan baik sebagai penuntut, pembela maupun juri. Maynard mendeskripsikan tentang rasionalitas dan elemen irasional hukum termasuk fakta, biografi, dan lainnya yang digunakan untuk mengkonstruksikan penawaran pengampunan dan membentuk putusan. Tipe analisa ini membantu untuk memahami bagaimana sumber rasional dan irasional hukum digunakan dalam menyelesaikan putusan putusan yang spesifik.

Tipologi yang dibuat oleh Weber ${ }^{14}$ tentang hukum juga memberikan kesempatan untuk mengembangkan pemahaman yang lebih jelas dari rule of law. Cara ini menunjukkan di mana institusi hukum, prosedur dan pola-pola yang paling rasional. Rule of law menandai perubahan sosial dan kebudayaan yang secara historis berakar pada pergolakan melawan pemerintahan yang menindas dan melawan tekanan arbitrase dan kekuatan politik. Pada satu level, rule of law adalah cara untuk membatasi kekuatan semau-maunya dengan memungkinkan untuk mengartikulasikan perdebatan melalui prosedur yang disediakan kepada setiap orang dan diberikan kepada

13 "Interpretive sociology is distinct from sheer subjective interpretation by the identification of a particular motive of conduct in terms of a broader frame of normativity. What this means is that for any human action to be sociologically interpreted, it must be shown to have a motive that makes sense to the actor as a member of a society or a subsection threof, within its own distinct culture, structurs, norms and expectations." (Sosiologi interpretatif berbeda dari interpretasi subyektif belaka dengan mengidentifikasi motif perilaku tertentu dalam kerangka normativitas yang lebih luas. Ini berarti bahwa agar tindakan manusia apa pun ditafsirkan secara sosiologis, itu harus ditunjukkan memiliki motif yang masuk akal bagi aktor sebagai anggota masyarakat atau subbagian, dalam budaya, struktur, norma, dan harapan yang berbeda). Baca Mathieu Deflam, Sociology of Law Visions of a Scholarly Tradition (Cambridge: Cambridge University Press, 2008), hlm. 40.

14 Weber menyusun tipologi hukum dengan kunci rasionalitas. Ada empat tipe ideal hukum yaitu (1) irasional material (2) irasional formal (3) rasional material (4) rasional formal (Saifullah, Refleksi Sosiologi Hukum [Bandung: PT. Refika Aditama, 2007], hlm. 44-45) 
semua partai suatu kesempatan yang sama untuk mempresentasikan argumen dan bukti.

Berdasarkan pada apa yang telah dijelaskan mengenai rule of law sebagai sebuah kondisi tindakan yang bersifat struktural dan kultural, sebuah masyarakat berkarakter rule of law apabila memenuhi dua kondisi. Pertama, hukum adalah sumber paling utama dari tatanan sosial. Institusi-institusi sosial seperti sekolah, institusi ekonomi seperti bisnis dibatasi dan diatur dengan hukum. Konflik diselesaikan dengan hukum, orang-orang mempunyai akses terhadap kekeuatan negara untuk melindungi kontrak dan harta kekayaannya serta untuk mendapat kompensasi dari kerugian yang mereka terima melalui hukum. Kedua, ketika ada elemen-elemen yang berkontribusi dalam tatanan hukum, termasuk pengetahuan dan prosedur-prosedur yang didasarkan pada ilmu pengetahuan dan tradisi, tipe hukum rasional formal lebih dominan dibandingkan dengan tipe yang lain. Pembuatan dan penerapan hukum mempunyai karakteristik rasional formal.

\section{Kapitalisme dan Rule of Law}

Salah satu ciri khas dari kekuasaan hukum dalam masyarakat kapitalis adalah wataknya yang palsu, khususnya terjadi akibat kelas yang berkuasa memberi dukungan terhadap kekuasaan hukum. Dalam telaah Marx terhadap para pembuat undang-undang, kenyataannya masyarakat dirumuskan "sembarangan" dengan menggunakan baju rasionalitas hukum yang formal dan kemudian dinyatakan berlaku sah kekuasaan hukumnya. ${ }^{15}$

Terdapat perbedaan dalam masyarakat sejauh mana mereka diatur berdasarkan konsep rule of law. Dalam hal ini bukan hanya masyarakat yang memiliki keterbatasan secara teknis, organisasi dan kompleksitas ekonomi, melainkan juga masyarakat yang unggul dalam pengembangan teknologi dan pertumbuhan ekonomi. Dalam masyarakat liberal klasik dengan ekonomi kapitalis kompetitifnya

15 Ahmad Zaenurrosyid, "Pergumulan Rule of Law dan Politik Kapitalisme dalam Konteks Keindonesiaan”, Jurnal Review Politik, 6, 2 (2016), hlm. 257. 
memperlihatkan suatu hubungan yang paling logis dan secara empirik sesuai dengan rule of law. Pada masyarakat seperti ini dikarakteristikkan dengan pola desentralisasi yang tinggi dari kekuatan produksi dan hubungan pasar, persaingan dan rasionalitas. Pola hukumnya imparsial, diatur pemerintah dan rasional yang membantu dalam membuat tindakan, khususnya perencanaan ekonomi untuk produksi dan tukar menukar. Pola seperti ini lebih aman dan dapat diprediksi.

Para sarjana telah mempertahankan bahwa khususnya di Amerika Serikat (AS) pada abad 19, liberalisme klasik dan kapitalisme kompetitif cenderung untuk membangun melalui liberalisme korporat dan kapitalisme korporat. Di bawah kapitalisme korporasi, firma-firma besar berkembang, yang menginvestasikan dana dalam jumlah besar dan memperkerjakan ribuan tenaga kerja dalam proses produksi. Dengan kapitalisme korporat, masyarakat menjadi lebih produktif dan terjadi kenaikan konsumsi.

Kapitalisme korporat dan liberalisme korporat merupakan implikasi besar pada perkembangan hukum pada umumnya dan rule of law pada khususnya. Satu ciri yang penting dari hubungan antara kapitalisme korporat dan liberalisme korporat dengan rule of law adalah bagaimana cara rule of law memfasilitasi dan mewujudkan perubahan dari liberalisme klasik dan kapitalisme kompetitif menjadi liberalisme korporat dan kapitalisme korporat.

Bahwa di samping adanya pendekatan studi hukum dan masyarakat yang memberikan perhatian khusus pada telaah ilmu politik dan aktivitas politik pemerintah dan para elit ekonomi dalam memformulasikan suatu kebijakan hukum dan sosial, para ilmuwan yang mengkaji hukum dan masyarakat juga memfokuskan kajiannya pada bagaimana aspek aspek dari ideologi the rule of law membentuk organisasi-organisasi sosial dan ekonomi di satu sisi dan kebijakan publik disisi lain. Memang tidak dapat dipungkiri lagi bahwa hukum mempunyai peran yang sangat signifikan dalam menciptakan hubungan-hubungan ekonomi, sosial dan politik pada hidup dan kehidupan masyarakat.

Prinsip-prinsip rule of law berkaitan erat dengan the enforcement 
of the rules of law dalam penyelenggaraan pemerintahan, terutama dalam hal penegakan hukum dan implementasi prinsip-prinsip rule of law. Berdasarkan pengalaman berbagai negara dan hasil kajian, menunjukkan bahwa keberhasilan the enforcement of the rules of law bergantung pada kepribadian nasional setiap bangsa. ${ }^{16} \mathrm{Hal}$ ini didukung oleh kenyataan bahwa rule of law merupakan institusi sosial yang memiliki struktur sosiologis yang khas dan mempunyai akar budayanya yang khas pula, ${ }^{17}$ yang juga merupakan gagasan tentang hubungan antar manusia, masyarakat, dan negara, yang dengan demikian memuat nilai-nilai tertentu yang memiliki struktur sosiologisnya sendiri.

Berangkat dari realitas sosiologis tersebut nampak adanya peran dari institusi-institusi hukum yang mengatur pola interaksi sosial, ekonomi dan politik kemasyarakatan yang sekaligus juga sebagai tempat penyelesaian bila terjadi disharmonisasi dalam hubunganhubungan tersebut. Untuk menggambarkan peran dari institusiinstitusi hukum dalam menciptakan pranata sosial dan ekonomi di AS khususnya bagaimana proses terbentuknya masyarakat liberal korporat, kiranya perlu disimak penelitian yang dilakukan oleh Martin Sklar ${ }^{18}$ tentang proses terbentuknya liberalisme korporat di

16 Sunaryati Hartono, Hukum Ekonomi Pembangunan Indonesia (Bandung: Bina Cipta, 1982), hlm. 53.

17 Baso Madiong, Sosiologi Hukum: Suatu Pengantar (Makassar: CV. Sah Media, 2014), hlm. 58.

18 Dari hasil penelitian Martin Sklar ditunjukkan bagaimana peran signifikan yang saling mempengaruhi antara lembaga Supreme Court, kasus hukum dan penalaran hukum serta politik hukum dalam meletakkan fondasi pranata ekonomi korporat di AS antara 1890-1916. Pada kurun waktu tersebut sejarah mencatat terjadinya perubahan sosial secara fundamental dan besar besaran di AS yakni ketika awal terjadi transformasi masyarakat AS ke tataran masyarakat industrial modern. Pada catatan sejarah dalam periode inilah mahakarya teknologi teknologi besar diketemukan, mekanisasi teknologi pertanian dilaksanakan, pembangunan infrastruktur jalur KA dibangun secara besar-besaran (untuk mempermudah processingbound logistics, processing, out-bound logistic), pembangunan ekonomi secara besar-besaran termasuk dimulainya sistem produksi masal pada kota-kota industri di AS. Lebih jauh lihat Martin J. Sklar, The Corporate Reconstruction of American Capitalism, 1890-1916: The Market, the Law and Politics (Cambridge: Cambridge University Press, 1988), hlm. 65. 
AS. Sejak saat itu AS resmi bertransformasi menjadi negara industri dengan ditandai oleh adanya pranata sosial yang baru yakni pranata masyarakat industri.

Institusi perbankan telah menjadi pusat kekuatan ekonomi yang mampu mengakumulasi dana masyarakat untuk menggerakkan roda perekonomian. Berangkat dari realitas inilah tata kelola dan pranata sosial yang baru dibangun dalam struktur kemasyarakatan AS. Pranata sosial yang baru inilah yang mampu mengakumulasikan berbagai sumberdaya (keuangan, intelektual dan material) secara bersama sama untuk mengendalikan produksi dan distribusi berladaskan pranata hukum dan pranata masyarakat industri yang kemudian dinamai sebagai korporasi modern.

Transformasi sosial ini pada hakikatnya terbentuk juga karena adanya pranata hukum yang baru yang melindungi investasi, mampu mengakumulasi modal masyarakat yang dari paranata hukum yang baru ini memungkinkan munculnya bisnis-bisnis berskala kecil di bidang produksi dan pertanian yang bisa mereka kendalikan secara langsung. Bisnis-bisnis kecil inilah yang ke depannya bisa tumbuh berkembang dengan pesat karena adanya dukungan sumberdaya keuangan dan bantuan teknis manajerial yang berorientasi pada keuntungan (profit making entity). Di era inilah lahir apa yang sekarang dikenal sebagai pasar bursa, di mana sebagian masyarakat pemilik modal memainkan perannya untuk mendapatkan keuntungan finansial walau yang bersangkutan tidak menjalankan bisnis secara langsung.

Dari pengumpulan dana masyarakat yang bersifat lokal (local capital gain), lambat laun bertransformasi menjadi lingkup regional dan internasional yang dari pola ini tentunya melahirkan relasirelasi bisnis yang baru yang terus berkembang bagaikan gurita bisnis yang berskala global. Tentunya transformasi bisnis seperti ini disamping akan merubah pula pranata pranata sosial yang ada, juga merubah sistem politik dan pranata hukum yang baru untuk melindungi kepentingan-kepentingan korporasi kapitalisme tersebut. Pertumbuhan bisnis dari skala lokal menuju skala global inilah yang kemudian melahirkan banyak persoalan-persoalan hukum khususnya 
yang menyangkut hak atas pengendalian harga, pengendalian pasar, persoalan buruh dan sebagainya. Inilah inti dari persoalan-persoalan hukum di era itu. Pemecahan persoalan-persoalan tersebut secara bijak dipecahkan lewat lembaga-lembaga hukum dan melalui penalaran hukum.

Dengan adanya konflik-konflik yang meluas dan kompleks sifatnya maka upaya untuk melindungi dan membentengi diri terhadap persaingan yang tak terkendalikan maka bagi kelompok kelompok usaha marginal dilindungi dengan payung hukum yang memungkinkan mereka tetap bisa terjamin kelangsungan hidup usahanya. Di sinilah peran serta institusi hukum dan pemerintah dibutuhkan yakni untuk membuat regulasi-regulasi guna melindungi kepentingan-kepentingan bisnis kelompok pengusaha marginal. Sedangkan mekanisme pengendalian bisnis dilakukan oleh publik lewat mekanisme pasar modal yang senantiasa menjunjung tinggi konsep-konsep transparasi dan akuntabilitas publik.

Di samping fenomena kehidupan usaha-usaha kecil tersebut, satu hal yang perlu digarisbawahi pada era ini adalah munculnya konsep pendekatan-pendekatan korporasi liberal yang menaungi bisnis-bisnis raksasa. Kelompok usaha ini juga membutuhkan regulasi dari pemerintah utamanya dalam persoalan-persoalan yang menyangkut buruh dan pasar walau keuntungan bisnisnya menjadi domain privat. Pendekatan liberal korporat ini mengombinasikan rasionalisasi ekonomi dan birokrasi sebagai pilihan utama daripada hanya mengandalkan diri pada pendekatan pasar saja. Pendekatan politik ekonomi seperti ini mampu menumbuhkan raksasa-raksasa bisnis di AS (milik publik) dimana peran serta pemerintah dibutuhkan lewat rasionalisasi hukum untuk mendorong pertumbuhan dan kelangsungan bisnis.

Persoalan utama yang mengedepan pada era itu adalah siapa yang menentukan pola pengendalian pasar dan bagaimana pasar diorganisasi. Persoalan-persoalan seperti ini dipecahkan lewat perdebatan yang panjang dan melelahkan dalam legislasi Antitrust. Salah satu yang terkenal adalah Sherman Antitrust Act yang ditandatangani oleh Presiden Benjamin Harrison pada 1890. Sherman 
Antitrust Act merupakan wujud peran serta negara melalui institusi hukum yang dalam hal ini adalah Supreme Court, dalam mengatur kehidupan usaha di AS agar kondusif dan terbebas dari praktik bisnis yang monopolistis. Kandungan dari Antitrust ini merupakan gabungan dari berbagai sumber hukum dari yang bersifat prinsip hukum hingga konstitusi negara.

Dari sinilah dengan atas nama konstitusi negara, pemerintah federal AS menelorkan kebijakan ekonominya demi kemaslahatan masyarakat luas dan demi tumbuh suburnya iklim usaha. Kebijakan ekonomi pemerintah federal AS pada waktu itu telah memberikan kekuasaan yang lebih besar terhadap korporasi di bawah regulasiregulasi yang ada. Inilah wujud liberalisme korporasi di AS dan dinamika politik, ekonomi dan hukum pada saat itu sebagai bukti kemenangan fahamliberalisme korporasidalamsistemperekonomian AS pada waktu itu.

\section{Telaah Paradigmatik terhadap Pemikiran Gerald Turkel mengenai Masyarakat Liberal, Rasionalitas, dan The Rule of Law}

Bagian ini akan menelaah tulisan Gerald Turkel sebagaimana yang secara dominan disajikan sebelumnya. Pertama-tama kebaruan tulisan ini daripada lainnya yang juga membahas pemikiran Gerald Turkel adalah upaya menelisik pemikiran Turkel secara filsafati dengan cara menganalisis paradigma karya yang dibahas dalam artikel ini “dialirkan” oleh penulisnya, Gerald Turkel. Hal ini penting, karena melalui paradigma dapat dimahami alur pemikiran secara baik, jelas, bahkan rinci, sebagaimana dijanjikan oleh pemahaman paradigma itu sendiri.

Sebelum lebih jauh melangkah, perlu ditegaskan pemahaman paradigma yang dijadikan acuan atau standpoint dalam telaah ini, yaitu pemahaman paradigma menurut Guba dan Lincoln. Paradigma sejatinya merupakan suatu sistem filosofis "payung" yang meliputi ontologi, epistemologi, dan metodologi tertentu. Masing-masingnya terdiri dari serangkaian "belief dasar" atau worldview yang tidak dapat 
begitu saja dipertukarkan (dengan "belief dasar" atau worldview dari ontologi, epistemologi, dan metodologi paradigma lainnya). ${ }^{19}$ Melalui pemahaman inilah, Guba dan Lincoln dalam penelitiannya menunjukkan bahwa dalam dunia ini terdapat empat paradigma yang "hidup" bersama-sama, dianut oleh komunitas pemeluknya masing-masing, yakni positivisme, pos-positivisme, critical theory, dan konstruktivisme.

Berdasarkan pemahaman paradigma tersebut, perlu ditelaah pemikiran Turkel dalam bab tiga bukunya Law and Society: Critical Approaches, yaitu "Liberal Society, Rationality, and the Rule of Law". Hal ini merupakan bagian paling menarik dalam perenungan dalam artikel ini, mengingat penelusuran paradigma yang menuntun lahirnya tulisan ini, cukup terbuka untuk "diduga" atau "diprediksi" melalui tuntutan set basic belief ontologi, epistemologi, dan metodologi.

Ditelaah secara paradigmatik, tulisan Turkel tersebut sesungguhnya (masih) "terbingkai” dalam pemahaman paradigma positivisme. Namun demikian, prediksi ini bukanlah satu-satunya, karena melalui karya tersebut pembaca diajak secara perlahan-lahan namun pasti untuk memasuki "dunia" paradigma critical theory, sebagaimana kental terasa pada pemikiran Turkel dalam bab-bab setelahnya.

Kesimpulan mengenai paradigma positivisme yang melatarbelakangi penulisan "Liberal Society, Rationality, and the Rule of Law" ini, pertama-tama terlihat dalam judulnya, yaitu "Masyarakat Liberal, Rasionalitas, dan the Rule of Law". Perlu ditegaskan bahwa analisis paradigma dalam artikel ini terbatas bab ini saja, bukan terhadap isi buku (Law and Society: Critical Approaches) secara keseluruhan. Hal ini akan berbeda, karena secara parsial pada bagian ini masih mendeskripsikan konsep-konsep hukum yang masih termasuk dalam pemahaman paradigma positivisme, utamanya mengenai rule of law, sementara pada bagian lainnya akan dapat dipahami bahwa Turkel

19 Guba, E.G. dan Lincoln, Y.S. "Competing Paradigms in Qualitative Research". Dalam Handbook of Qualitative Research, ed. N.K. Denzin dan Y.S. Lincoln (London: Sage Publications, Inc., 1994), hlm. 105-117. 
sedang melakukan kritik terhadap konsep-konsep hukum umum seperti rule of law, dalam "tuntunan" paradigma critical theory.

Untuk menuju simpulan paradigmatik yang tepat terhadap tulisan Turkel ini, artikel ini mengurai analisis dalam set basic belief baik secara ontologis, ${ }^{20}$ epistemologis, ${ }^{21}$ dan metodologis. ${ }^{22}$ Pertama, aspek ontologis atau dapat dipahami sebagai hakikat realitas, dapat dilihat pada makna realitas hukum yang terlihat dalam tulisan ini. Secara hampir keseluruhan, hukum ideal yang cocok dan diharapkan dapat menjaga stabilitas pada tatanan masyarakat liberal adalah hukum yang bersifat rasional formal, dalam bingkai rule of law. Supremasi hukum menjadi satu keharusan yang harus ditegakkan dalam rangka melayani aturan, mampu menjadi alat kalkulasi, sekaligus memprediksi keluaran/hasil yang impersonal dan obyektif. Berikut ini penjelasan mengenai rule of law yang dikutip kembali dari tulisan Turkel.

Rule of law tidak berorientasi untuk mengarah pada tujuan sosial atau penyelesaian problem-problem sosial melalui pembuatan dan implementasi kebijakan. Hukum bukan sebuah arena untuk penyelesaian permasalahan kemiskinan, pengangguran, atau ketiadaan asuransi kesehatan. Sebaliknya, rule of law menjaga stabilitas tatanan individu dan bisnis untuk mengejar keuntungan ekonomi mereka. Jadi ini merupakan kerangka untuk menjalankan aktivitas sosial dan ekonomi. Rule of law memperlakukan sama dan tidak memihak terhadap setiap orang.

Memahami dengan seksama realitas hukum sebagaimana dipahami melalui konsep rule of law, sebagaimana dipaparkan sebelumnya, maka terlihat sisi ontologis realitas dalam paradigma positivisme. Sebagaimana realitas dimengerti oleh penganut

20 Pertanyaan ontologis adalah pertanyaan dasar mengenai bentuk dan sifat realitas, berikut apa yang dapat diketahui mengenai hal ini (Indarti, Diskresi dan Paradigma, hlm. 18).

21 Pertanyaan epistemologis adalah pertanyaan dasar mengenai sifat hubungan atau relasi antara individu atau kelompok masyarakat dengan lingkungan atau segala yang ada di luar dirinya, termasuk apa yang dapat diketahui tentang hal ini (Indarti, Diskresi dan Paradigma, hlm. 18).

22 Pertanyaan metodologis adalah pertanyaan dasar mengenai cara bagaimana individu atau kelompok masyarakat (tentunya termasuk peneliti) mendapatkan jawab atas apa yang ingin diketahuinya tersebut (Indarti, Diskresi dan Paradigma, hlm.18). 
positivisme, realitas dikehendaki bersifat eksternal, riil, obyektif, dapat dipahami begitu saja karena sudah tekstual, bersifat generalisasi, bebas konteks, dan reduksionis. Semua sifat-sifat realitas tersebut dapat terlihat secara jelas dalam prinsip rule of law. Justru melalui prinsip rule of law ini, segala makna mengenai hukum harus selalu bersifat rasional dan formal, tertuang dalam bentuknya yang menjamin kepastian.

Sementara, jika analisis paradigmatik secara epistemologis diuji, maka dapat terlihat bahwa pemahaman hukum yang diusung dalam prinsip rule of law menunjukkan sifat hubungan antara subyek dan obyek (realitas) adalah dualistik atau obyektif sebagaimana epistemologi paradigma positivisme. ${ }^{23} \mathrm{Hal}$ ini berarti makna hukum menurut prinsip rule of law tidaklah menghendaki adanya keterkaitan dengan nilai atau dapat disebut bebas nilai, sehingga hukum yang demikian harus selalu diselenggarakan secara obyektif. Inilah satusatunya jalan untuk melanggengkan aktivitas sosial ekonomi, dalam konteks liberalisme dan kapitalisme, karena segalanya harus dapat dikontrol atau diprediksi, justru jika tidak melibatkan subyektivitas sama sekali.

Adji Samekto juga berpandangan bahwa konsepsi the rule of law sebenarnya hanya merupakan "pegangan untuk permainan, bukan untuk menciptakan hasil yang mencerminkan substantive justice". ${ }^{24}$ Oleh karenanya objektivitas dan rasionalitas menjadi kriteria yang menentukan dalam konsepsi rule of law. Dengan kata lain, rule of law sebenarnya hanya berkaitan dengan prosedur-prosedur formal.

Secara metodologis, paradigma positivisme menggunakan eksperimental/manipulatif, di mana metode dalam implementasi hukum dilakukan dengan menggunakan model verifikasi, sehingga hukum hanya diselenggarakan sesuai dengan peraturan-peraturan yang sudah dibuat dan tidak memungkinkan ruang kritis di sana.

23 Aditya Yuli Sulistyawan, "Mempersoalkan Objektivitas Hukum: Suatu Perbincangan Filsafat Hukum”, Masalah-Masalah Hukum, 41, 4 (2012), hlm. 511.

24 FX. Adji Samekto, "Relasi Hukum dengan Kekuasaan: Melihat Hukum dalam Perspektif Realitas”, Jurnal Dinamika Hukum, 13, 1 (2013), hlm. 94. 
Model yang seperti ini adalah metode yang dikehendaki oleh hukum yang diusung oleh prinsip rule of law.

Sebagaimana sudah disampaikan sebelumnya, paradigma positivisme bukan satu-satunya paradigma yang terlihat dalam pemikiran Turkel melalui bab tiga bukunya Law and Society: Critical Approaches. Nafas paradigma critical theory sebetulnya cukup terlihat pada bagaimana Turkel mengajak pembaca untuk sekaligus membongkar realitas hukum yang diwakili oleh prinsip rule of law. Meskipun pada bagian ini upaya pembongkaran hukum ala critical belum terlihat jelas sebagaimana pada bab-bab berikutnya, nuansa tersebut terlihat pada penjelasan bahwa hukum-hukum yang dibuat untuk mendukung kapitalisme, sesungguhnya tidak dapat dipisahkan sama sekali dengan proses politik, ekonomi, dan sejarah yang melatarbelakanginya, sebagaimana ciri realitas menurut paradigma critical theory.

Bahkan, nuansa paradigma konstruktivisme juga cukup terlihat pada beberapa bagian pemikiran Turkel pada tulisan ini. Misalnya ketika ia menyampaikan model hukum di Jepang, di mana penyelesaian kasus-kasus hukum tidak semata-mata menggunakan peraturan perundang-undangan, tetapi juga upaya non-penal, seperti mediasi dan segala bentuknya yang memungkinkan proses dialog untuk mencapai kesepakatan. Hal ini menunjukkan cukup jelas "nafas" konstruktivisme yang juga muncul dalam tulisan ini, selain secara jelas ditunjukkan dengan metode interpretatif yang sesungguhnya khas konstruktivisme.

Melalui pembacaan "Liberal Society, Rationality, and the Rule of Law", terlihat bahwa pemikiran Turkel sejatinya berada dalam rentang paradigma positivisme hingga critical theory, bahkan melampaui sampai kepada paradigma konstruktivisme. Dari rentang ini dapat ditunjukkan bahwa pemikiran Turkel berada dalam rentang epistemologis objektif-subjektif sebagaimana rentang epistemologi paradigma-paradigma tersebut. Oleh karenanya, artikel ini menyebutnya sebagai "titik perdamaian" kedua epistemologi objektif-subjektif, yaitu paradigma pos-positivisme. Inilah paradigma yang menuntun pemikiran Turkel sebagai eksponen aliran pemi- 
kiran Law and Society. Paradigma pos-positivisme memiliki ontologi realisme kritis yang menampung pemaknaan realitas secara objektif dan subjektif, di mana meskipun realitas masih ditentukan pada objektivitas sebagai kriteria penentu, namun pemikiran atau intelektualitas subjek/penelaah secara subjektif turut memengaruhi pemaknaan suatu realitas. Di sinilah standpoint Turkel terbaca dalam telaahnya tentang liberalisme dan rasionalisme sebagai basis rule of law ini.

\section{Kesimpulan}

Artikel ini menyimpulkan, pertama, terdapat benang merah hubungan antara liberalisme klasik, rasionalitas, kapitalisme kompetitif, dan ideologi rule of law, dalam hal ini rule of law yang dijelaskan berdasarkan tipologi pengambilan keputusan hukum yang dikemukakan oleh Max Weber dan pandangannya tentang rasionalitas dan tindakan sosial. Definisi ini menunjukkan karakteristik sebuah masyarakat di mana kehidupan ekonomi, penyelesaian konflik dan penyediaan akses ke dalam kekuasaan negara diatur oleh hukum. Kedua, ideologi rule of law merupakan faktor yang sangat penting dalam konstruksi transisi dari kapitalisme kompetitif dan liberalisme klasik ke kapitalisme korporat dan liberalisme korporat di Amerika Serikat. Dengan kata lain, ideologi rule of law terlibat dalam persoalan-persoalan politik ekonomi dan solusi atas persoalan-persoalan tersebut di Amerika Serikat utamanya pada abad ke 19. Ketiga, ditelaah secara paradigmatik, karya Gerald Turkel "Liberal Society, Rationality, and the Rule of Law", yang merupakan bagian dari bukunya Law and Society: Critical Approaches, sesungguhnya (masih) "terbingkai" dalam pemahaman paradigma positivisme. Namun demikian, prediksi ini bukanlah satu-satunya, karena melalui tulisan tersebut pembaca diajak untuk secara perlahan-lahan namun pasti memasuki "dunia" paradigma critical theory, sebagaimana kental terasa pada bagian lainnya daribuku tersebut. Penjelasan secara ontologis, epistemologis, dan metodologis terhadap realitas hukum yang diusung oleh prinsip rule of law pada tatanan masyarakat liberalisme menunjukkan bahwa 
Turkel dituntun oleh paradigma pos-positivisme dalam menjelaskan relasi liberalisme, rasionalitas, dan rule of law. Hal ini memungkinkan kritik dilakukan oleh Turkel dalam nafas ontologi "realisme kritis".

\section{Daftar Pustaka}

Deflam, Mathieu. Sociology of Law visions of a Scholarly Tradition. Cambridge: Cambridge University Press, 2008.

Guba, E.G. dan Lincoln, Y.S. "Competing Paradigms in Qualitative Research". Dalam Handbook of Qualitative Research, diedit oleh N.K. Denzin dan Y.S. Lincoln, 105-117. London: Sage Publications Inc., 1994.

Hamzani, Achmad Irwan, "Menggagas Indonesia sebagai Negara Hukum yang Membahagiakan Rakyatnya”. Yustisia Jurnal Hukum, 3, 3 (2014): 137-142. DOI: 10.20961/yustisia.v3i3.29562. Hartono, Sunaryati. Hukum EkonomiPembangunan Indonesia. Bandung: Bina Cipta, 1982.

Indarti, Erlyn. "Diskresi dan Paradigma: Sebuah Telaah Filsafat Hukum”. Pidato Pengukuhan Guru Besar Filsafat Hukum pada Fakultas Hukum Universitas Diponegoro. Semarang: Badan Penerbit Undip, 2010.

Madiong, Baso. Sosiologi Hukum: Suatu Pengantar. Makassar: CV. Sah Media, 2014.

McCarthy, Thomas. Teori Kritis Jurgen Habermas. Terjemah oleh Nurhadi. Yogyakarta: Kreasi Wacana, 2006.

Muabezi, Zahermann Armandz. "Negara Berdasarkan Hukum (Rechtstaats) Bukan Kekuasaan (Machtstaat). Jurnal Hukum dan Peradilan, 6, 3 (2017): 421-446. DOI: 10.25216/JHP.6.3.2017.421446.

Saifullah. Refleksi Sosiologi Hukum. Bandung: PT. Refika Aditama, 2007.

Samekto, FX. Adji. Justice Not for All. Yogyakarta: Genta Press, 2008. Samekto, FX. Adji. "Relasi Hukum dengan Kekuasaan: Melihat Hukum dalam Perspektif Realitas". Jurnal Dinamika Hukum, 13, 1 (2013): 89-98. DOI: 10.20884/1.jdh.2013.13.1.157. 
Scott, Bruce R. Capitalism, Its Origin and Evolution as a System of Governance. New York: Springer, 2011.

Setiadi, Wicipto. "Pembangunan Hukum dalam Rangka Peningkatan Supremasi Hukum", Jurnal Rechtsvinding: Media Pembinaan Hukum Nasional, 1, 1 (2012): 1-15.

Sklar, Martin J. The Corporate Reconstruction of American Capitalism, 1890-1916: The Market, the Law and Politics. Cambridge: Cambridge University Press, 1988.

Sulistyawan, Aditya Yuli. "Mempersoalkan Objektivitas Hukum: Suatu Perbincangan Filsafat Hukum”. Masalah-Masalah Hukum, 41, 4 (2012): 505-512. DOI: 10.14710/mmh.41.4.2012.505-512.

Turkel, Gerald. Law and Society: Critical Approaches. Toronto: A. Simon \& Schuster Company Needham Heights, MA., 1996.

Unger, Roberto M. Teori Hukum Kritis: Posisi Hukum dalam Masyarakat Modern. Terjemah oleh Dariyatno dan Derta Sri Widowati. Bandung: Penerbit Nusa Media, 2010.

Vago, Steven. Law and Society. New Jersey: Prentice Hall, edisi keempat, 1994.

Zaenurrosyid, Ahmad. "Pergumulan Rule of Law dan Politik Kapitalisme dalam Konteks Keindonesiaan”. Jurnal Review Politik, 6, 2 (2016): 195-219. 